\title{
Perbedaan Hasil Belajar Fisika Antara Model Pembelajaran Inkuiri Terbimbing dengan Model Pembelajaran Kooperatif Tipe Make and Match Pada Siswa Kelas VIII SMP Negeri 9 Palu
}

\author{
Listin Yuniarti, Muhammad Ali, dan I Wayan Darmadi \\ Listinyuniartindeusu19@gmail.com \\ Program Studi Pendidikan Fisika FKIP Universitas Tadulako \\ Jl. Soekarno Hatta Km. 9 Kampus Bumi Tadulako Tondo Palu - Sulawesi Tengah
}

\begin{abstract}
Abstrak - Penelitian ini dilakukan dengan tujuan menguji signifikansi perbedaan hasil belajar fisika antara kelompok siswa yang diberi pembelajaran dengan model pembelajaran inkuiri terbimbing dengan kelompok siswa yang diajar dengan model pembelajaran kooperatif tipe make and match kelas VIII SMP Negeri 9 Palu. Jenis penelitian ini menggunakan metode quasi experimental design yang diterapkan pada dua kelas eksperimen yaitu kelas VIII. Sampel dipilih dengan menggunakan teknik purposive sampling. Jumlah sampel kelas eksperimen pertama 26 orang dan kelas eksperimen kedua 24 orang. Teknik analisa data yang digunakan pada penelitian ini yaitu uji normalitas, uji homogenitas, dan uji hipotesis. Instrumen yang digunakan berupa tes hasil belajar dalam bentuk pilihan ganda. Berdasarkan tes hasil belajar fisika pada materi getaran dan gelombang, menunjukkan bahwa nilai rata-rata untuk kelas inkuiri terbimbing yaitu 17,23 dan standar deviasi sebesar 2,83, dan nilai rata-rata hasil belajar siswa untuk kelas kooperatif tipe make and match yaitu 15,29 dan standar deviasi sebesar 3,07. Hasil uji t dua pihak dengan $\mathrm{dk}=48$ dan taraf signifikansi $\alpha=0,05$ diperoleh nilai $t_{\text {hitung }}=2,40$ dan nilai ini lebih besar dari $t_{\text {tabel }}=1,68$ Nilai thitung berada di luar daerah penerimaan $\mathrm{H}_{0}$, dengan demikian $\mathrm{H}_{0}$ ditolak dan $\mathrm{H}_{1}$ diterima, sehingga dapat disimpulkan bahwa terdapat perbedaan yang signifikan pada hasil belajar fisika antara siswa yang diberi pembelajaran dengan model pembelajaran inkuiri terbimbing dengan siswa yang diberi pembelajaran dengan model pembelajaran kooperatif tipe make and match.
\end{abstract}

Kata Kunci : Inkuiri terbimbing ( guided inqury ), Kooperatif tipe Make and Match, Hasil Belajar Fisika

\section{PENDAHULUAN}

Pendidikan merupakan salah satu kebutuhan manusia sepanjang hayat. Dengan demikian pendidikan harus diarahkan untuk membentuk manusia yang berkualitas, mampu bersaing, memiliki budi pekerti yang luhur dan bermoral yang baik. [1]

Proses belajar mengajar, secara umum melibatkan empat buah komponen utama, yaitu: siswa, guru, lingkungan belajar, dan materi pelajaran. Setiap siswa mempunyai tingkat kemampuan yang berbeda jika ditinjau dari daya tangkap terhadap pelajaran, pengetahuan yang dimilikinya dalam bidang yang akan dipelajari, motivasi belajar, keterampilan belajar, tujuan belajar dan lainlain.[2]

Siswa cenderung pasif dan sulit memahami materi yang diberikan oleh guru. Sehingga mengakibatkan minimnya kemampuan siswa untuk mengeluarkan pendapat dan minimnya pemahaman siswa terhadap materi fisika yang diberikan. Hal ini, berdampak pada hasil belajar siswa yang cukup rendah. Untuk mengatasi kesulitan belajar siswa seorang guru mampu untuk mengembangkan model pembelajaran yang efektif dan menyenangkan saat belajar terutama pada mata pelajaran fisika.

Model pembelajaran yang dapat melibatkan keaktifan siswa selama pembelajaran dan pembelajaran dengan suasana belajar yang efektif dan menyenangkan yaitu antara lain model pembelajaran inkuiri terbimbing (guided inquiry) dan model pembelajaran Kooperatif Tipe Make And Match. Penelitian dengan menggunakan kedua model ini telah banyak dilakukan antara lain dengan menerapkan model pembelajaran Kooperatif tipe make and match untuk meningkatkan hasil belajar siswa kelas VIIa SMP Negeri 1 Tomini Pada Konsep gerak.[3] dan menerapkan model pembelajaran inkuiri terbimbing ( Guided Inquiry) Terhadap Hasil Belajar Fisika Pada Konsep Listrik Dinamis. [4]

Penerapan model pembelajaran inkuiri terbimbing ini dapat meningkatkan aktivitas belajar siswa dalam proses pembelajaran dan untuk mengembangkan siswa yang mandiri, siswa diharuskan untuk mendesain atau merancang penyelidikan, menganalisa hasil dan sampai pada kesimpulan [5]. Sedangkan model 
pembelajaran kooperatif tipe Make And Match merupakan model pembelajaran mencari pasangan dan model pembelajaran ini mampu membuat siswa dapat menguasai konsep dengan cara yang menyenangkan.[6]

Tujuan dalam penelitian ini adalah untuk mengetahui perbedaan hasil belajar fisika antara model pembelajaran inkuiri terbimbing dengan model pembelajaran kooperatif tipe make and match pada siswa kelas VIII SMP Negeri 9 Palu.

\section{METODE PENELITIAN}

Jenis penelitian ini adalah penelitian metode quasi experimental design yang merupakan penelitian kuantitatif. Adapun desain penelitian ini menggunakan "The non equivalen pretestposttest design" penelitian ini dilaksanakan menggunakan dua kelas yang dijadikan sebagai kelas eksperimen. Bentuk desain penelitiannya disajikan pada Tabel 1. [7]

TABEL 1. DESAIN PENELITIAN "THE NON EQUIVALEN PRETEST-POSTTEST

\begin{tabular}{cccc}
\hline \multicolumn{4}{c}{ DESIGN" } \\
\hline Group & Tes Awal & Perlakuan & Tes Akhir \\
\hline Inkuiri terbimbing & $\mathrm{O}$ & $\mathrm{X}_{1}$ & $\mathrm{O}$ \\
Make and match & $\mathrm{O}$ & $\mathrm{X}_{2}$ & $\mathrm{O}$ \\
\hline
\end{tabular}

Keterangan :

$\mathrm{X}_{1}$ : Model Pemebelajaran Inkuiri Terbimbing

$\mathrm{X}_{2}$ : Model pembelajaran kooperatif tipe make and match

O :Tes awal (preetest) dan Tes akhir (postest)

Populasi dalam penelitian ini sebanyak 207 orang yang terdiri dari 9 kelas siswa kelas VIII SMP Negeri 9 Palu tahun ajaran 2015/2016. Sampel dalam penelitian ini terdiri dari 2 kelas dengan jumlah sampel 26 orang untuk kelas dengan model inkuiri terbimbing dan 24 siswa untuk kelas dengan model kooperatif tipe make and match. Penarikan sampel pada penelitian ini ditentukan dengan metode pengambilan sampel yang digunakan secara purposive sampling atau penentuan sampel dengan pertimbangan tertentu.

Instrumen yang digunakan dalam penelitian ini adalah RPP, LKS, dan tes belajar. Tes tersebut digunakan untuk mengetahui kemampuan hasil belajar siswa. Tes dibuat dalam bentuk tes pilihan ganda yang berjumlah 35 soal. Sebelum diuji cobakan pada kelas yang menjadi kelas eksperimen, terlebih dahulu diuji coba pada kelas IX di SMP Negeri 9 Palu yang telah melewati materi getaran dan gelombang, setelah diuji cobakan kemudian dilakukan analisis butir soal meliputi: validasi item, indeks kesukaran, daya pembeda, reliabilitas tes dan langkah terakhir yaitu pengambilan keputusan untuk tiap soal. Data yang diperoleh dari penelitian ini selanjutnya diolah menggunakan uji statistik yaitu uji normalitas, uji homogenitas, dan uji hipotesis yaitu uji-t (dua pihak).

\section{HASIL DAN PEMBAHASAN}

\section{A. Hasil penelitian}

Instrumen soal yang dibuat oleh peneliti berjumlah 35 soal, sebelum soal digunakan untuk menentukan kemampuan siswa pada kelas eksperimen terlebih dahulu diuji coba pada kelas IX.

Hasil analisis uji validitas item diperoleh rentang $r_{p b i}$ antara $-0,10-0,79$ dari hasil ini soal yang masuk dalam kategori sangat rendah berjumlah 8 soal, kategori rendah berjumlah 1 soal, kategori sedang berjumlah 26 soal.

Besar nilai reliabilitas tes pada penelitian ini dibandingkan dengan nilai realibilitas tes yang ditentukan dalam tabel adalah ( $\mathrm{r}_{\text {hitung }}(0,82)>$ $r_{\text {tabel }}(0,70)$ ). Dari hasil tersebut dapat dikatakan bahwa nilai reliabilitas tes hasil perhitungan lebih besar dibandingkan nilai realibilitas tes yang ditentukan. Berdasarkan hasil tersebut dapat dinyatakan bahwa tes hasil belajar fisika siswa pada materi getaran dan gelombang yang disusun dapat memberikan hasil yang tetap, atau mempunyai taraf kepercayaan yang tinggi. Dengan kata lain, sejauh mana suatu tes dapat dipercaya untuk menghasilkan skor yang tetap, relatif tidak berubah walaupun diteskan pada situasi yang berbeda-beda.

Berdasarkan hasil analisa data yang diperoleh dari 36 item tes yang diuji cobakan pada siswa kelas VIII, tes yang memenuhi syarat untuk digunakan sebagai tes hasil belajar siswa adalah sebanyak 26 item. Penggunaan tes awal diberikan untuk melihat kemampuan awal siswa dengan membandingkan hasil belajar sebelum diberi perlakuan.

Setelah tes awal, setiap kelas eksperimen diberikan perlakuan yaitu kelas inkuiri terbimbing dan kelas kooperatif tipe make and match. Selanjutnya dilakukan tes akhir untuk mengetahui perbedaan hasil belajar dari kedua kelas eksperimen tersebut. Data dapat dilihat pada tabel 2 . 
TABEL 2. DESKRIPSI SKOR TES HASIL BELAJAR FISIKA SISWA UNTUK

\begin{tabular}{lcccc} 
& \multicolumn{3}{c}{ KELAS EKSPERIMEN } \\
\cline { 2 - 5 } Uraian & $\begin{array}{c}\text { Inkuiri } \\
\text { terbimbing }\end{array}$ & $\begin{array}{c}\text { Make } \\
\text { and } \\
\text { match }\end{array}$ & $\begin{array}{c}\text { Inkuiri } \\
\text { terbimbing }\end{array}$ & $\begin{array}{c}\text { Make } \\
\text { and } \\
\text { match }\end{array}$ \\
\hline $\begin{array}{l}\text { Sampel (n) } \\
\text { Nilai }\end{array}$ & 26 & 24 & 26 & 24 \\
$\begin{array}{l}\text { Maksimum } \\
\text { Nilai }\end{array}$ & 12 & 11 & 22 & 20 \\
$\begin{array}{l}\text { Minimum } \\
\text { Skor rata- } \\
\text { rata } \\
\begin{array}{l}\text { Standar } \\
\text { deviasi }\end{array}\end{array}$ & 8.11 & 8.08 & 17,23 & 15,29 \\
\hline
\end{tabular}

Sebelum dilakukan pengujian hipotesis terlebih dahulu dilakukan uji normalitas dan uji homogenitas data. Hasil uji normalitas dan uji homogenitas menunjukkan bahwa data ini sudah terdistribusi normal dan homogen.

Setelah uji normalitas dan uji homogenitas, maka di lakukan uji-t (dua pihak ). Berdasarkan skor tes akhir (posttest) pada kelas eksperimen diperoleh nilai thitung $=2,40$ dan tabel $=1,68$. Dari hasil analisa data tes akhir yang ada diperoleh bahwa $\mathrm{H}_{0}$ ditolak sedangkan $\mathrm{H}_{1}$ diterima atau dengan kata lain terdapat perbedaan hasil belajar fisika siswa yang mengikuti model pembelajaran Inkuiri Terbimbing dengan model pembelajaran kooperatif tipe Make and match.

\section{B. Pembahasan}

Penggunaan tes awal dilakukan untuk melihat kemampuan awal siswa, rerata skor yang diperoleh pada tes awal (pretest) kedua kelas 8,11 untuk kelas inkuiri terbimbing dan 8,08 untuk kelas kooperatif tipe make and match. Pemberian pretest pada kedua kelas tersebut, dapat diketahui bahwa ternyata belum terdapat perbedaan hasil belajar yang signifikan antara kedua kelas eksperimen. Dari data hasil analisis terlihat bahwa hasil belajar kedua kelas tersebut masih rendah.

Setelah diberi perlakuan model pembelajaran inkuiri terbimbing dan model kooperatif tipe make and match kedua kelas tersebut memperoleh peningkatan hasil belajar dari keadaan awal. Hal tersebut dapat dilihat melalui hasil pemberian posstest. Kelas eksperimen diketahui skor rata- rata untuk kelas Inkuiri terbimbing 17,23 dan untuk kelas kooperatif tipe make and match 15,29.

Berdasarkan hasil penelitian tersebut dapat dilihat bahwa dengan memberikan perlakuan yang berbeda pada kelas ekperimen, akan memperoleh hasil belajar yang berbeda. Perbedaan hasil belajar tersebut dapat dilihat dari skor pretes maupun skor posttest pada kelas ekperimen yang menunjukkan adanya perbedaan model pembelajaran yang digunakan pada kedua kelas tersebut. Siswa pada kelas inkuiri tebimbing dituntut aktif dalam proses pembelajaran serta memudahkan siswa dalam mengusai konsep fisika melalui berpikir dan berdiskusi dengan teman sejawatnya. Sedangkan pada kelas kooperatif tipe make and match siswa juga dituntut untuk memecahkan masalah dengan batasan waktu yang singkat dengan mencocokan kartu jawaban dan soal yang dipegang masing-masing kelompok siswa, di dalam kelas dengan adanya bimbingan dari guru.

Tahap model pembelajaran inkuiri terbimbing ini diawali Model pembelajaran inkuiri terbimbing diawali dengan menumbuhkan rasa penasaran siswa dan keingintahuan siswa sebelum menerima materi yang diajarkan. Selanjutnya, siswa dihadapkan pada suatu permasalahan fisika yang berhubungan dengan kehidupan sehari-hari atau pengalaman nyata yang pernah dialami siswa untuk merangsang daya berpikir mereka. Hal ini dimaksudkan untuk menarik perhatian dan minat siswa dalam menghadapi pengalaman belajar yang akan diberikan. Selanjutnya siswa dihadapkan pada tujuan pembelajaran yang harus dicapai pada pembelajaran yang akan dilakukan.

Kegiatan pembelajaran selanjutnya yaitu mengorganisasikan siswa kedalam kelompok untuk melakukan kegiatan praktikum dan mendiskusikan permasalahan yang terdapat pada LKS yang diberikan. Setelah melakukan kegiatan praktikum, setiap kelompok diberikan kesempatan untuk menyelesaikan permasalahan yang terdapat pada LKS dan mempertanggung jawabkannya dengan cara mempersentasikan hasil diskusi kelompoknya didepan kelas sedangkan kelompok lain dapat menanggapinya dengan melakukan tanya jawab. Setelah kegiatan pembelajaran selesai, guru membimbing siswa untuk menarik kesimpulan bersama-sama.

Penelitian ini sejalan dengan penelitian sebelumnya [8] dengan judul pengaruh model pembelajaran inkuiri terbimbing (guided inquiry) terhadap hasil belajar siswa pada konsep getaran dan gelombang. Penelitian dilakukan di MTs Jamiatus Sholihin pada tahun pelajaran 2009-2010. Ada beberapa faktor yang menyebabkan model pembelajaran inkuiri terbimbing berpengaruh terhadap hasil belajar fisika siswa diantaranya yaitu: terlaksananya langkah-langkah kegiatan dengan model inkuiri terbimbing dalam proses pembelajaran, permasalahan yang disajikan dalam LKS mampu membangkitkan minat dan rasa ingin 
p-ISSN 2338-3240, e-ISSN 2580-5924

tahu siswa, alat-alat praktikum yang menunjang kegiatan pembelajaran dan adanya kesempatan siswa untuk mengkomunikasikan hasil diskusi.

Tahap model pembelajaran kooperatif tipe make and match untuk kelas eksperimen kedua, diawali dengan menyajikan tujuan pembelajaran yang harus dicapai oleh siswa pada pembelajaran yang akan dilakukan. Setelah itu, guru menyajikan garis-garis besar materi pembelajaran yang akan dipelajari dan mengorganisasikan siswa kedalam kelompok yang terdiri dari kelompok soal dan jawaban, siswa diberikan waktu yang singkat untuk menemukan kartu yang sesuai dengan pasangannya. Setelah kegiatan pembelajaran selesai, guru menarik kesimpulan tentang materi yang telah dipelajari.[9]

Sesuai dengan penelitian terdahulu [10] dengan judul pengaruh model pembelajaran kooperatif tipe make and match terhadap hasil belajar siswa pada materi pokok alat- alat optik di kelas VIII semester II SMP Swasta Budi Agung Medan T.P. 2012/2013. Model kooperatif sangat berpengaruh terhadap hasil belajar karena model ini membuat siswa aktif saat belajar dengan cara menyenangkan dalam memahami dan membentuk konsep suatu materi.

Perbedaan hasil belajar yang diperoleh dari kedua kelas eksperimen disebabkan karena adanya kendala yang dialami saat melakukan proses pembelajaran pada masing-masing kelas eskperimen, beberapa kendala yang dialami pada kelas inkuiri terbimbing yaitu: mengalokasikan waktu dengan tepat, karena model pembelajaran inkuiri terbimbing ini memiliki tahapan yang cukup banyak, dan guru belum menguasai kelas.sedangkan pada kelas kooperatif tipe make and match yaitu: yaitu sulitnya mengalokasikan waktu pada tiap tahapan, sulit menentukan soal dan kartu jawaban yang tepat, sulit mengatur siswa sesuai model pembelajaran. Jadi inilah yang merupakan factor penyebab dari kecilnya nilai rata - rata tes akhir pada kelas make and match.

\section{KESIMPULAN}

Berdasarkan hasil penelitian yang telah dilakukan, dapat disimpulkan bahwa terdapat perbedaan hasil belajar fisika antara model pembelajaran inkuiri terbimbing dengan yang mengikuti model pembelajaran kooperatif tipe make and match pada siswa kelas VIII SMP Negeri 9 Palu. Berdasarkan hasil pengujian hipotesis statistik uji rata-rata pada taraf nyata $a=0,05$ yaitu thitung $=2,40$ dan harga $t_{\text {tabel }}=$ 1,67. Hal ini menunjukan bahwa harga thitung $>$ tabel sehingga $\mathrm{Ho}$ ditolak dan $\mathrm{H}_{1}$ dapat diterima.

\section{DAFTAR PUSTAKA}

[1] Aris. 2011. Penerapan Pembelajaran Kooperatif Tipe Make A Macth Terhadap Hasil Belajar Fisika Siswa pada konsep cahaya. Skripsi sarjana pada fkultas FKIP UIN Jakarta.

[2] Sagala, Syaiful (2013). Konsep dan Makna Pembelajaran. Bandung : Alpabeta

[3] Mikran, 2013. Penerapan Model Pembelajaran Kooperatif Make And Match Untuk Meningkatkan Hasil Belajar Siswa Kelas Viia SMP Negeri 1 Tomini Pada Konsep Gerak : Jurnal Pendidikan fisik Tadulako JPTF. Vol 2.no.2

[4] Sofiani, E s. 2011. Skripsi yang Berjudul: Pengaruh Model Inkuiri Terbimbing (Guided Inquiry) Terhadap Hasil Belajar Fisika Pada Konsep Listrik Dinamis. PU UIN Jakarta

[5] Sudjana. 2007. Metode Statistik. Bandung: Tarsito 2010

[6] Elyani, I. 2011. Pengaruh Model Pembelajaran Inkuiri terbimbing terhadap Hasil Belajar Fisika Pada Konsep Getaran dan Gelombang. Jakarta. Skripsi sarjana pada fakultas FKIP UIN.

[7] Huda, M. 2012. Cooperatif Learning : Metode, Teknik, Teori Struktur dan Model Terapan. Yogyakarta : Pustaka Belajar.

[8] Karyono. 2009 . Skripsi dengan judul : Pengaruh Metode Guided-Inquiry Melalui Pembelajaran Bernuansa Nilai Terhadap Hasil Belajar Biologi Siswa. PU UIN Jakarta.

[9] Aqib, Z. 2013. Model-model Media dan Strategi Pembelajaran Kontekstual (Inovatif). Bandung : Yrama Widya

[10] Sirait, M. 2013. Pengaruh model pembelajaran kooperatif tipe make and match terhadap hasil belajar siswa : Jurnal INPAFI.vol 1.no.3 